\title{
Reptile Responses to Lantana Management in a Wet Sclerophyll Forest, Australia
}

\author{
Author(s): Diana A. Virkki, Cuong Tran, and J. Guy Castley \\ Source: Journal of Herpetology, 46(2):177-185. 2012. \\ Published By: The Society for the Study of Amphibians and Reptiles \\ DOI: http://dx.doi.org/10.1670/11-225 \\ URL: http://www.bioone.org/doi/full/10.1670/11-225
}

BioOne (www.bioone.org) is a nonprofit, online aggregation of core research in the biological, ecological, and environmental sciences. BioOne provides a sustainable online platform for over 170 journals and books published by nonprofit societies, associations, museums, institutions, and presses.

Your use of this PDF, the BioOne Web site, and all posted and associated content indicates your acceptance of BioOne's Terms of Use, available at www.bioone.org/page/terms_of_use.

Usage of BioOne content is strictly limited to personal, educational, and non-commercial use. Commercial inquiries or rights and permissions requests should be directed to the individual publisher as copyright holder. 


\title{
Reptile Responses to Lantana Management in a Wet Sclerophyll Forest, Australia
}

\author{
Diana A. VirkKi, ${ }^{1,2}$ CuOng Tran, ${ }^{1}$ and J. Guy Castley $^{1,3}$ \\ ${ }^{1}$ Environmental Futures Centre, School of Environment, Griffith University, Gold Coast, Queensland 4222, Australia
}

\begin{abstract}
AвSTRACT.-Lantana (Lantana camara L., Verbenaceae) is an invasive species of global interest that threatens more than 300 Australian plant and animal species of conservation significance. Reptiles may be at high risk due to their ground-dwelling habit and reliance on microhabitat structure. We examined the effects of lantana, and its management, on reptile assemblages in a wet sclerophyll forest in southeast Queensland, Australia. We compared reptile assemblages across four treatments: (i) manual clearing and herbicide application; (ii) herbicide application followed by prescribed burn; (iii) untreated lantana thickets; and (iv) wet sclerophyll forest. Plots treated with herbicide and then burned were structurally more diverse than manually cleared sites and supported a greater diversity of reptiles. No species occurred exclusively in untreated lantana habitats; however, these plots supported relatively high abundances of rare species, particularly Challenger Skinks (Saproscincus rosei). Lantana also had a higher species richness compared to manually cleared and sclerophyll forest. The use of lantana as habitat by a number of species highlights the need to consider the importance of these habitats for fauna prior to implementing management options. Herbicide application followed by prescribed burning appears to be an ideal approach to manage lantana due to the increased heterogeneity and regrowth of native vegetation, an option which supported more diverse reptile communities. Our results caution against the whole scale clearing of lantana from invaded areas, as these habitats continue to support reptile communities including threatened species. Nevertheless, by treating lantana with herbicide and prescribed fire, reptile community structure might be maintained.
\end{abstract}

Habitat invasion by exotic weed species is one of the most globally significant environmental issues affecting biodiversity of natural ecosystems (Fensham et al., 1994; Thuiller et al., 2005; Sinden and Griffith, 2007). Exotic weeds alter ecosystem functioning by modifying habitats, competing with native flora, and suppressing native fauna, thereby placing additional pressure on already vulnerable species (Groves et al., 2003; Thuiller et al., 2005; Gooden et al., 2009b). Lantana (Lantana camara L., Verbenaceae) is a global weed established in almost 50 countries (Sharma et al., 2007). In Australia, lantana thrives in numerous forests along the eastern coastline (Day et al., 2003; Sharma et al., 2007), covering over 5\% of Australia's landscape (Turner and Downey, 2008). Lantana invasion is listed as a Key Threatening Process to more than 1,386 Australian plant and animal species, including over 300 species of conservation significance, prompting its listing as a Weed of National Significance (WONS) (Groves et al., 2003; Turner and Downey, 2010).

Few studies have considered the impacts of lantana on Australian terrestrial fauna, with most studies focusing on birds (Liddy, 1985; Smith et al., 1998; Goth and Vogel, 2002) and small mammals (Goosem et al., 2001; Goosem et al., 2006). More recently, attention has shifted to reptiles, where Turner and Downey (2010) found that the greatest number of high priority animal species threatened by lantana were reptiles, through species displacement, or those "considered at risk" where more information is required. A number of reptile species were also identified as positively affected by lantana; however, fewer reptiles benefit from lantana compared with birds and mammals (Turner and Downey, 2010).

Reptiles may be at high risk from lantana due to their grounddwelling habit and reliance on microhabitat structure for foraging, basking, and refuges (Hadden and Westbrooke, 1996; Singh et al., 2002; Fischer et al., 2005). Lantana alters habitat structure due to its thicket-forming nature (Swarbrick et

\footnotetext{
${ }^{2}$ Corresponding Author. E-mail: d.virkki@griffith.edu.au

${ }^{3}$ Present address: International Centre for Ecotourism Research, School of Environment, Griffith University, Gold Coast, Queensland 4222, Australia.
}

DOI: $10.1670 / 11-225$ al., 1995; Day et al., 2003; Sharma et al., 2007; Gooden et al., 2009a), potentially affecting reptile microhabitats.

In Australia, lantana has been established for over $160 \mathrm{yr}$ (Sharma et al., 2005) and may have resulted in landscape homogenization (Hiremath and Sundaram, 2005; Gooden et al., 2009b). Reptilian responses to homogenization depend on the loss of particular habitat features (Fischer et al., 2005; Valentine and Schwarzkopf, 2009). Maximizing reptilian diversity therefore requires the maintenance of habitat heterogeneity at both the microhabitat and landscape scales (Fischer et al., 2005). Homogenization by lantana may affect key physiognomic characteristics that determine reptile occupancy including shrub complexity, canopy cover, litter cover, coarse woody debris (CWD), disturbance history (i.e., fire history), and soil characteristics (Hadden and Westbrooke, 1996; Garden et al., 2007).

Notwithstanding the potential impacts associated with lantana itself, management of this weed may also impact on natural habitats (Hobbs and Humphries, 1995; Zavaleta et al., 2001; Gooden et al., 2009a; Valentine and Schwarzkopf, 2009). Little consideration has been given to the long-term benefits or the ecological consequences of weed management practices (Zavaleta et al., 2001; Valentine and Schwarzkopf, 2009). Broadscale weed removal can denude habitats (Swarbrick et al., 1995), significantly affecting microhabitats vital for reptile assemblages (Valentine and Schwarzkopf, 2009). It is therefore important to consider the flow-on effects of weed management strategies before undertaking large-scale clearing or management in order to minimize the effects on reptiles. While this emphasizes the need for well-defined adaptive management objectives (Hobbs and Humphries, 1995; Zavaleta et al., 2001), there are limited quantitative data available to guide these decisions.

Australian lantana management guidelines advocate an integrated approach combining the conventional methods of (i) chemical control, (ii) manual removal, and (iii) control by fire (Day et al., 2003; NHT, 2003; Stock et al., 2009). While this approach may lead to more ecologically desirable outcomes for vegetation communities (Day et al., 2003), the potential implications of these integrated approaches for faunal communities, particularly reptiles, is poorly understood.

Here, we examined the effects of lantana and its removal on reptile assemblages in a wet sclerophyll forest by comparing 


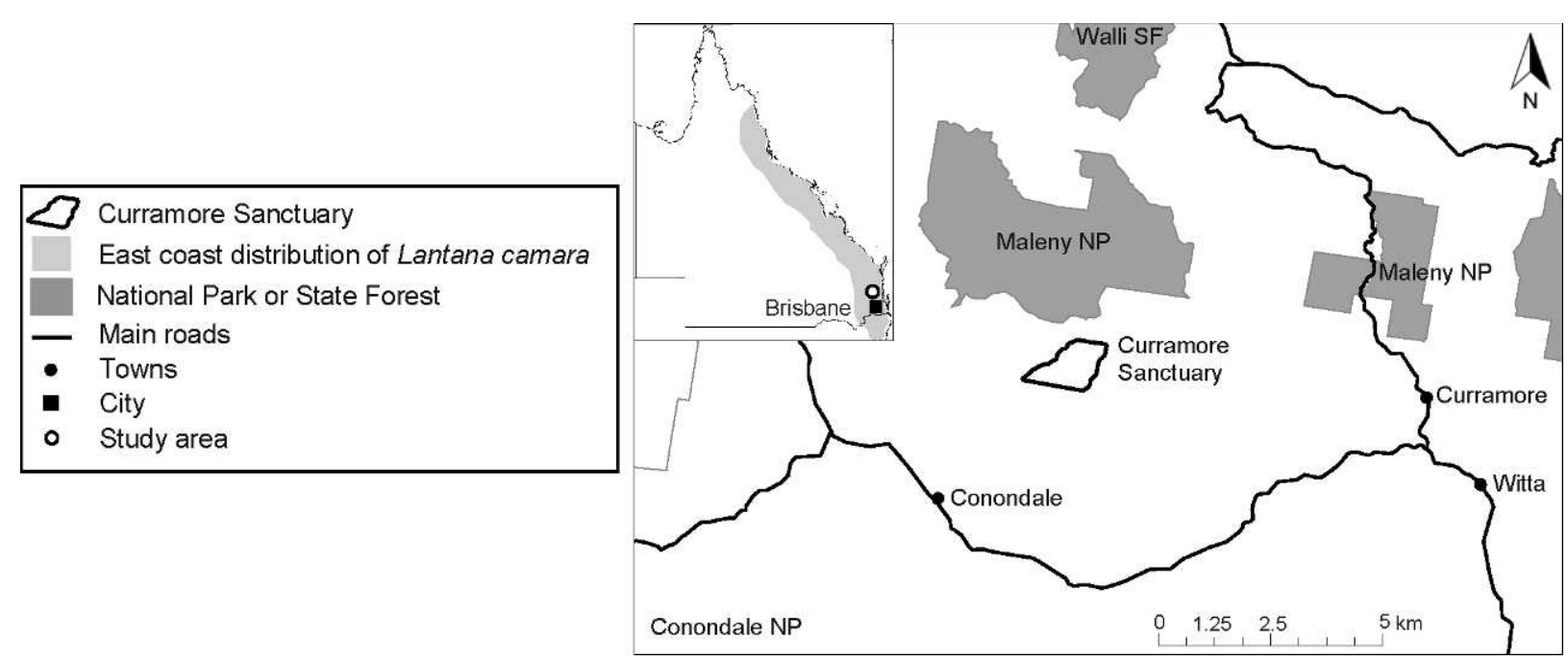

FIG. 1. Map of study area, Curramore Sanctuary, showing the location within the east coast distribution of Lantana camara in Queensland (CHAH 2010).

two integrated management approaches in a small-scale experimental field study. We firstly tested the hypothesis that lantana-invaded habitats support depauperate reptile communities and, secondly, that lantana management which reduces the structural integrity of habitat would reduce reptile diversity.

\section{Materials AND Methods}

Study Site and Treatments.-This study was undertaken in Curramore Sanctuary $\left(29^{\circ} 40^{\prime} 56^{\prime \prime} \mathrm{S}, 152^{\circ} 44^{\prime} 23^{\prime \prime} \mathrm{E}\right)$, a 175-ha Australian Wildlife Conservancy (AWC) reserve reaching $661 \mathrm{~m}$ elevation and located on the western edge of the Blackall Ranges, southeast Queensland, Australia (Fig. 1). Curramore is a forest mosaic dominated by wet sclerophyll forest communities (EPA, 2008). It is primarily tall, open forest with Sydney bluegum (Eucalyptus saligna) or flooded gum (Eucalyptus grandis), open forest of grey ironbark (Eucalyptus siderophloia), grey gum (Eucalyptus propinqua), and white mahogany (Eucalyptus acmenoides), and some pockets of simple notophyll vine forest usually with Bangalow palm (Archontophoenix cunninghamiana) (gully vine forest) on Cenozoic igneous rocks and near coastal hills on Mesozoic to Proterozoic igneous rocks (EPA, 2008). The sanctuary is surrounded by the human-transformed habitats of the Maleny Plateau. Lantana has been present at Curramore for over $50 \mathrm{yr}$ (P. Stanton, pers. comm.) and, since acquisition by AWC in 2003, there have been concerted efforts to re-establish the natural habitats as functional ecosystems. Current management strategies have combined herbicide spraying, manual clearing, and prescribed burns.

This study was limited by existing weed management practices undertaken by land managers. We therefore used space-for-time substitution (Pickett, 1991; Tyre et al., 2000; Krebs, 2003; Croft et al., 2010) in a small-scale experimental study to investigate the effects of two lantana treatments on reptile assemblages in a wet sclerophyll forest. The experimental design utilized two lantana treatment types as well as a control (existing untreated lantana thickets) and reference site (undisturbed wet sclerophyll forest). Treatments consisted of a manually cleared, herbicide-sprayed site and a site that was herbicide-sprayed along with prescribed fire.

Treatments were not replicated at the landscape scale owing to site and management constraints; therefore, six replicate plots were used within each treatment area (totaling 24 plots) consisting of approximately 0.25 ha and separated by 18-115 m. This distance was considered sufficient for independence, since small skinks are known to rarely travel distances further than $20 \mathrm{~m}$ (Fischer et al., 2004). Treatment application was conducted by AWC using a staged approach to the management of lantana at Curramore; manual clearing and herbicide application occurred 6-9 months before the initial reptile surveys, with the herbicide-prescribed fire treatment completed 6 months before the study. Manual clearing was by machete and herbicide (10\% glyphosate) using a modified gaspropelled spray gun that allowed for large-scale use. Spotspraying was used as a follow-up treatment to limit regrowth (Totland et al., 2005). The burn treatment had a similar herbicide application followed by a dieback period of between 3-6 months before a low intensity fire was applied in September 2007.

Reptile Surveys.-Reptile abundance and composition were assessed at each site using pitfall traps and time-constrained passive searches during five surveys in April, May, September, October, and November 2008. Each survey included three trap nights and three searches per plot. Pitfall trap arrays consisted of two 20-L plastic buckets per plot, equating to 12 traps per treatment. These were buried flush with the ground at both ends of a 10-m drift fence which stood $25 \mathrm{~cm}$ high, supported by galvanized metal rods ( $5 \mathrm{~mm}$ thick) and buried $5 \mathrm{~cm}$ below the ground (Singh et al., 2002). We placed pitfall traps in the center of the plots and the fence followed local topography. In the untreated lantana control, we cleared a 1-m wide track through the center of the lantana thicket to facilitate trap setup and future access. We also cleared two additional tracks for searches and habitat surveys.

To complement the pitfall trapping, passive searching was implemented along two 25-m transects at each plot for 20 person-minutes. To eliminate bias in visibility among the different treatment types, searches were conducted within 1-2 $\mathrm{m}$ of the observer to standardize the results (as was consistent with the visibility experienced along the tracks within lantana plots). We identified all observations to species where possible (Wilson, 2005). However, unidentified reptiles were assigned to a single, non-specific group (Singh et al., 2002) 
called "litter skinks" in order to compare the relative abundance of reptiles among sites.

Habitat Attributes.-We measured twelve habitat attributes potentially influencing reptile communities, and most-likely affected by weed management, along three $25 \mathrm{~m}$ transects placed randomly at least $4 \mathrm{~m}$ apart and that followed the local topography (Magnusson et al., 2005) on each plot. Using a randomized quadrat survey, we measured understory plant $\left(<0.5 \mathrm{~m}\right.$ high) and litter cover by placing ten quadrats $\left(1 \mathrm{~m}^{2}\right)$ spaced at least $1 \mathrm{~m}$ apart along transects (sensu Garden et al., 2007). We categorized the composition of the understory cover into ground vegetation (herbs, grasses, sedges, and ferns), shrubs (vines, shrubs, and seedlings), surface litter (leaf, bark, and twigs), palm frond litter, or lantana. We determined cover using visual estimates to the nearest percent within the quadrat for each category and then calculated the percentage cover of each category per plot.

We quantified the proportion of CWD and rocks at each site using a line-intercept method (Sutherland, 2006). We defined CWD as dead and decomposing woody material and included stumps and roots (Turner, 2007). Only rocks $>8 \mathrm{~cm}$ intercept length were measured, based on a calculation of the range and mean reptile size from surveys 1 and 2 (mean $=30.2 \mathrm{~cm}$ [SD \pm $10.5 \mathrm{~cm}]$; range $=12-60 \mathrm{~cm}$ ) and personal observations from the pilot study (D. Virkki, pers. obs.).

Light availability, aspect, elevation, and soil characteristics were measured using point surveys. Light penetration through the canopy was measured from the start, center, and end of each plot transect using a light meter at two heights; above shrubs $(2 \mathrm{~m})$ and below shrubs $(20 \mathrm{~cm})$. Aspect $\left(^{\circ}\right)$ and elevation $(\mathrm{m}$ A.S.L.) were measured from two points (12 m apart) at each site using a compass and GPS, respectively. We determined soil attributes by taking three $120-\mathrm{mL}$ samples $(10 \mathrm{~cm}$ of top soil) per plot from the center of each transect. Each sample was classified separately according to McDonald et al. (1998) using a bolus and ribbon test to determine the soil type and mean silt and clay content.

\section{DATA ANALYSIS}

Reptile Communities.-Reptile abundance data were standardized as number of captures/hour (i.e. captures/24 h for pitfall traps) and data from both searches and pitfall traps were pooled. Unidentified reptiles were only analyzed in comparing overall relative abundances among treatments. In all analyses, all Lampropholis skinks that were identified to species were analyzed separately as well as pooled into a group called "Lampropholis spp." which included both unidentified and identified Lampropholis individuals.

Trends within treatment type were consistent over time; therefore, we pooled the data across all survey periods to increase statistical rigor. A dissimilarity matrix of reptile composition (captures/hour) data of all species using BrayCurtis distance measures was created (Brown, 2001; Clarke and Gorley, 2006). Reptile species that explained most of the variation in the composition data were determined using BIOENV (Clarke and Gorley, 2006).

Effects of Treatment.-Total reptile abundance (captures/hour) and species richness were compared among treatments using one-way analysis of variance (ANOVA) (Zar, 2007). We analyzed treatment effects on reptile composition using analysis of similarities (ANOSIM) on the dissimilarity matrix of reptile data (Brown, 2001; Clarke and Gorley, 2006). We undertook additional pairwise post hoc analyses in order to determine which of the treatments were statistically different before displaying these treatment patterns using non-metric multidimensional scaling (MDS) plots (Clarke and Ainsworth, 1993; Clarke and Gorley, 2006). On the MDS plots we also displayed correlated $(r>0.5$ correlation using Pearson's correlation) (Clarke and Warwick, 1994) reptile species as vectors in order to show any patterns in the composition of reptiles among treatments. We also made individual species comparisons among treatments using one-way ANOVA for species identified as being influential in previous analyses.

Determinants of Reptile Communities.-Habitat attribute data were normalized (subtract mean and divide by standard deviation) (Clarke and Ainsworth, 1993; Clarke and Gorley, 2006) prior to comparing the habitat attributes matrix among treatments using ANOSIM and pairwise post hoc tests. We generated a non-metric MDS from a Euclidean dissimilarity matrix (Clarke and Ainsworth, 1993) and displayed correlated habitat variables (Pearson's $r>0.5$; Valentine and Schwarzkopf, 2009) as vectors in order to show patterns in the habitat attributes among treatments. We further analyzed differences in habitat attributes among treatments using one-way ANOVA and least significant difference (LSD) post hoc tests (Gentle and Duggin, 1997).

To determine habitat characteristics important to reptiles, we explored meaningful statistical relationships between reptile assemblages and habitat attributes using BIOENV, which is commonly used to relate environmental variables to faunal data matrices (Norkko et al., 2000; Urbina-Cardona et al., 2006). We found the best combination of habitat attributes that correlated significantly ( $\alpha=0.05$ ) with reptile composition (captures/hour) by running 1,000 permutations. Individual influential reptile species were used to investigate relationships with habitat attributes using stepwise multiple regression analyses (Hadden and Westbrooke, 1996; Lindenmayer et al., 2009).

\section{Results}

Reptile Communities.-During the five survey periods, we observed a total of 739 individual reptiles of 15 species (four Elapidae, one Pythonidae, eight Scincidae, one Typhlopidae, and one Varanidae; Table 1). A total of six species were not found in lantana, four of which were observed only once including the Small-eyed Snake (Cryptophis nigrescens), Yellow-faced Whipsnake (Demansia psammophis), Rough-scaled Snake (Tropidechis carinatus), and Proximus Blind Snake (Ramphotyphlops proximus) (Table 1). Most of the variation in reptile composition was explained by Lampropholis spp. (94.4\%) and Challenger Skinks, Saproscincus rosei (4.0\%) for an accumulative total of $98.4 \%$ (BIOENV, $P<0.01$ ).

Effect of Treatment.- Species richness was significantly higher in burned and untreated lantana plots than in manually cleared plots (one-way ANOVA, $F=3.30, \mathrm{df}=3,20, P<0.05$ ) (Fig. 2a); however, overall richness was similar (Table 1). Significantly higher reptile numbers (captures/hour) were observed in manually cleared sites, and sclerophyll forest had significantly lower captures (one-way ANOVA, $F=6.54$, $\mathrm{df}=3,20, P<0.01$ ) (Fig. 2b). It was possible to discriminate among treatments based on the reptile composition of all species, which also differed significantly (ANOSIM, $R=0.344, P<0.001$ ) with three highly correlated $(r>0.5)$ species (Lampropholis spp., S. rosei, and Murray's Skink [Eulamprus murrayi]; Fig. 3). Similar trends were also observed from single species analyses, where Lampropholis 
TABLE 1. Abundance of reptile species observed over the course of this study showing total recorded abundance (T) and captures/hour (C/H) per treatment as well as abundance per plot (1-6) within each treatment.

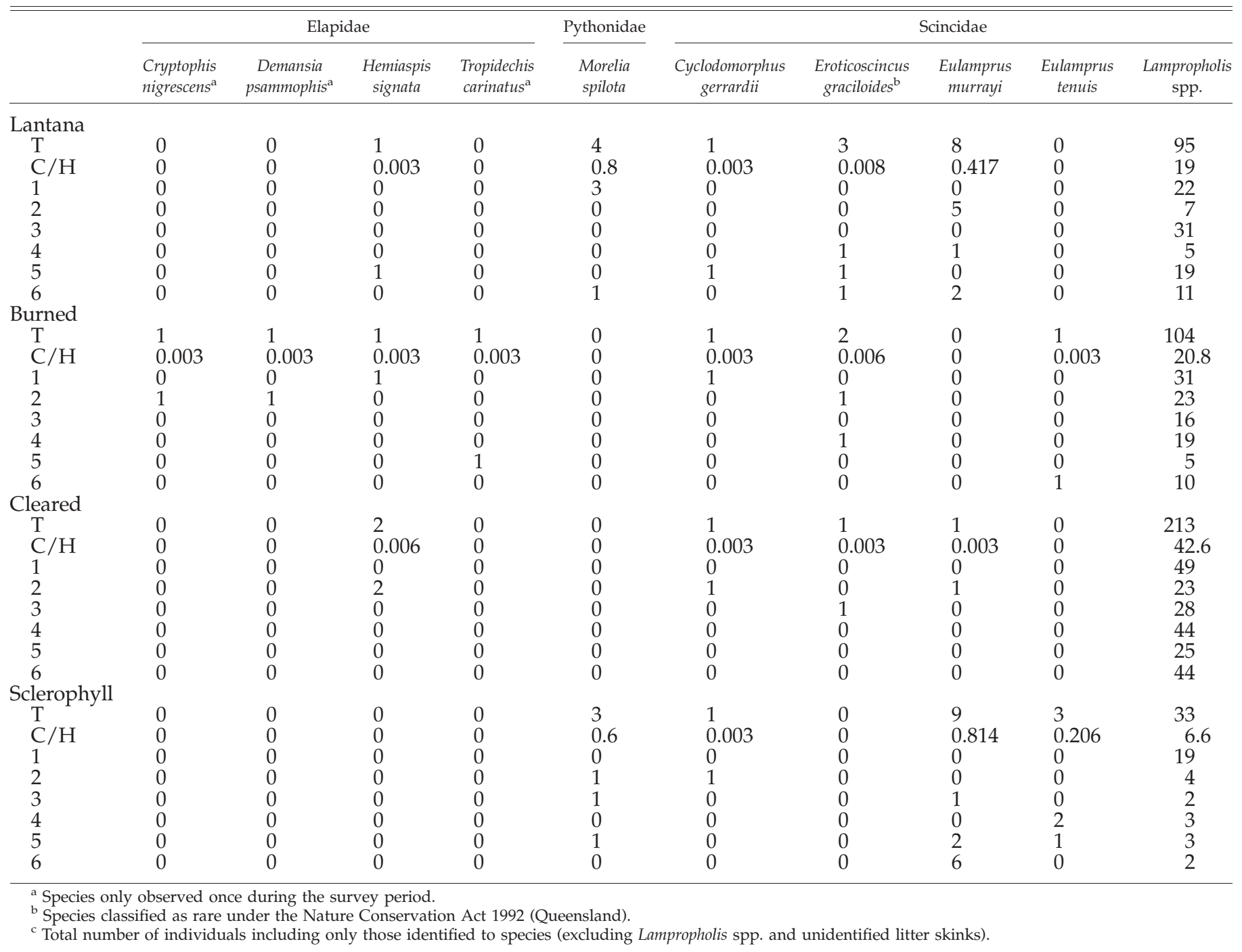

spp. abundance was significantly higher in cleared sites than in all other treatments and lower in sclerophyll forest (one-way ANOVA + LSD post hoc, $F=8.49, \mathrm{df}=3,20, P<0.01$ ), and significantly higher abundances of $S$. rosei were observed in untreated lantana (one-way ANOVA + LSD post hoc, $F=8.85$, $\mathrm{df}=3,20, P<0.01)$.

Determinants of Reptile Communities.-The four treatment types had distinctive habitat structures (ANOSIM, $R=0.48, P<0.05$; LSD post hoc, $P<0.05)$ due to a gradient of differing habitat attributes (Fig. 4), with 10 attributes contributing to these significant differences (Table 2). Untreated lantana was dominated by the weed in the understory, therefore having very low ground vegetation cover and an open canopy above which affected light availability (Fig. 4; Table 2). Sclerophyll forest sites were very dense and structurally diverse, with the lowest light availability, highest palm frond litter cover, and silt content in the soil (Fig. 4; Table 2). The burned sites were heterogeneous, with the highest CWD cover, and generally had a dense understory layer due to regenerative growth demonstrated by high cover values for both ground vegetation and shrubs (Table 2). This regenerative growth was of native species, with very little reestablishment of weeds recorded, especially of lantana (Table 2).
The manually cleared sites had lower shrub cover than the burned sites and the highest light availability below shrubs, highlighting the openness of the sites near the ground (Fig. 4; Table 2).

Habitat attributes that best explained reptile composition were the combination of palm frond litter and silt content in the soil, which explained $57.8 \%$ of the variation in the data (BIOENV, $P<0.01$ ). Both palm frond litter and silt content had significantly higher values in the undisturbed forest sites (Table 2), suggesting an overriding influence of this habitat type. Multiple regressions also detected significant correlations with habitat attributes for the most influential species. Lampropholis spp. were significantly correlated with clay content in the soil (multiple regression, $r^{2}=0.52, F=25.76, P<0.001$ ) and, importantly, $S$. rosei was significantly correlated with lantana cover, reflecting its high abundance at these sites (multiple regression, $r^{2}=0.60, F=33.43, P<0.001$ ).

\section{DisCUSSION}

Determinants of Reptile Communities.-The observed differences in habitat structure among the sites could be attributed to lantana 
TABLE 1. Extended.

\begin{tabular}{|c|c|c|c|c|c|c|c|c|c|}
\hline \multicolumn{5}{|c|}{ Scincidae } & $\frac{\text { Typhlopidae }}{\begin{array}{c}\text { Ramphotyphlops } \\
\text { proximus }^{\mathrm{a}}\end{array}}$ & 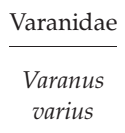 & $\begin{array}{c}\text { Total no. } \\
\text { of individuals }\end{array}$ & $\begin{array}{c}\text { Total no. } \\
\text { ID to species }\end{array}$ & $\begin{array}{l}\text { Total no. } \\
\text { of species }\end{array}$ \\
\hline $\begin{array}{l}7 \\
0.217 \\
3 \\
0 \\
2 \\
2 \\
0 \\
0\end{array}$ & $\begin{array}{l}15 \\
0.042 \\
10 \\
1 \\
6 \\
1 \\
2 \\
2\end{array}$ & $\begin{array}{l}26 \\
1.45 \\
3 \\
1 \\
13 \\
0 \\
2 \\
0\end{array}$ & $\begin{array}{l}38 \\
7.01 \\
2 \\
8 \\
6 \\
5 \\
12 \\
5\end{array}$ & $\begin{array}{l}12 \\
2.4 \\
3 \\
3 \\
2 \\
1 \\
3 \\
0\end{array}$ & $\begin{array}{l}0 \\
0 \\
0 \\
0 \\
0 \\
0 \\
0 \\
0\end{array}$ & $\begin{array}{l}0 \\
0 \\
0 \\
0 \\
0 \\
0 \\
0 \\
0\end{array}$ & $\begin{array}{l}210 \\
31.4\end{array}$ & $\begin{array}{l}103 \\
9.95\end{array}$ & 9 \\
\hline $\begin{array}{l}9 \\
1.01 \\
0 \\
0 \\
0 \\
2 \\
2 \\
5\end{array}$ & $\begin{array}{l}28 \\
0.078 \\
4 \\
11 \\
4 \\
10 \\
2 \\
3\end{array}$ & $\begin{array}{l}23 \\
1.25 \\
3 \\
7 \\
5 \\
2 \\
0 \\
0\end{array}$ & $\begin{array}{l}16 \\
1.23 \\
2 \\
3 \\
1 \\
9 \\
0 \\
1\end{array}$ & $\begin{array}{l}9 \\
1.8 \\
0 \\
4 \\
2 \\
3 \\
0 \\
0\end{array}$ & $\begin{array}{l}0 \\
0 \\
0 \\
0 \\
0 \\
0 \\
0 \\
0\end{array}$ & $\begin{array}{l}4 \\
0.8 \\
1 \\
1 \\
1 \\
0 \\
1 \\
0\end{array}$ & $\begin{array}{r}201 \\
27\end{array}$ & $\begin{array}{l}88 \\
4.392\end{array}$ & 12 \\
\hline $\begin{array}{l}2 \\
0.006 \\
0 \\
0 \\
0 \\
0 \\
1 \\
1\end{array}$ & $\begin{array}{l}16 \\
0.242 \\
1 \\
5 \\
0 \\
6 \\
3 \\
1\end{array}$ & $\begin{array}{l}5 \\
0.211 \\
2 \\
0 \\
0 \\
0 \\
1 \\
2\end{array}$ & $\begin{array}{l}7 \\
0.611 \\
0 \\
1 \\
0 \\
1 \\
3 \\
2\end{array}$ & $\begin{array}{l}2 \\
0.4 \\
0 \\
0 \\
2 \\
0 \\
0 \\
0\end{array}$ & $\begin{array}{l}0 \\
0 \\
0 \\
0 \\
0 \\
0 \\
0 \\
0\end{array}$ & $\begin{array}{l}1 \\
0.003 \\
1 \\
0 \\
0 \\
0 \\
0 \\
0\end{array}$ & $\begin{array}{l}251 \\
44.1\end{array}$ & $\begin{array}{l}36 \\
1.09\end{array}$ & 9 \\
\hline $\begin{array}{l}9 \\
0.617 \\
7 \\
2 \\
0 \\
0 \\
0 \\
0\end{array}$ & $\begin{array}{l}2 \\
0.006 \\
0 \\
2 \\
0 \\
0 \\
0 \\
0\end{array}$ & $\begin{array}{l}0 \\
0 \\
0 \\
0 \\
0 \\
0 \\
0 \\
0\end{array}$ & $\begin{array}{r}11 \\
2 \\
1 \\
7 \\
0 \\
0 \\
2 \\
1\end{array}$ & $\begin{array}{r}10 \\
3 \\
2 \\
1 \\
0 \\
0 \\
0 \\
0\end{array}$ & $\begin{array}{l}1 \\
0.003 \\
0 \\
0 \\
0 \\
0 \\
0 \\
1\end{array}$ & $\begin{array}{l}2 \\
0.4 \\
0 \\
0 \\
0 \\
0 \\
0 \\
2\end{array}$ & $\begin{array}{l}84 \\
14.3\end{array}$ & $\begin{array}{l}41 \\
4.65\end{array}$ & 9 \\
\hline
\end{tabular}

invasion, as noted in previous studies (Swarbrick et al., 1995; Gentle and Duggin, 1997; Sharma et al., 2007), or as a result of ongoing management of lantana. Distinct reptile communities were observed at Curramore Sanctuary among treatments, and those were influenced by local habitat structure.

The correlations found among reptiles and habitat attributes may be a response to lantana, as noted for S. rosei, but it is also possible that these responses are due to historical vegetation and habitat patterns as well as to lantana management. The importance of complex ground substrates for reptiles (Letnic et al., 2004; Garden et al., 2007) is in line with the high correlation of palm frond litter with reptiles detected here, as litter provides important refuges (Brown, 2001; Kanowski et al., 2006). The association with palm frond litter, specifically, has not been previously identified but is likely to mirror the importance of the cover and depth of other forms of litter, as shown by other studies (Brown, 2001; Kanowski et al., 2006; Valentine et al., 2007; Valentine and Schwarzkopf, 2009; Mott et al., 2010). The prevalence of silt in sclerophyll forest may not be directly important to reptiles but may be an artifact of the closed nature of these habitats, which have been shown to have higher quantities of silt (Islam and Weil, 2000).

Lantana habitats at Curramore supported a diverse reptile assemblage, highlighting its value as an important habitat.
Disturbed habitats (i.e., weedy or with weed-treatment applications) with canopy gaps may enhance reptile populations, particularly Lampropholis species as ubiquitous generalists that use disturbed areas and have a preference for cleared areas and forest edges (Wilson, 2005; Kanowski et al., 2006). Lantana thrives in canopy gaps with increased sunlight (Fensham et al., 1994; Swarbrick et al., 1995; Gentle and Duggin, 1998; Day et al., 2003), which may also confer an increase in available sunlight for use by basking reptiles, either in small gaps in the lantana or for reptiles that may climb the plants (Irschick et al., 2005; Downes and Hoefer, 2007). Members of the genus Lampropholis were abundant in untreated lantana, cleared, and burned sites and may have preferred the treatment sites because of the reduction in canopy cover caused by lantana clearing.

Two rare species, S. rosei and Elf Skinks, Eroticoscincus graciloides, (as classified under the 1992 Nature Conservation Act of Queensland) recorded at Curramore usually inhabit rainforest and wet sclerophyll forest with a very restricted range in southeast Queensland (Wilson, 2005). There were both recorded in all treatments, although $S$. rosei was significantly more abundant in untreated lantana. The use of lantana habitat by $S$. rosei has been previously reported (DECC, 2008) and has important management implications. Saproscincus species generally only require microhabitats associated with leaf litter 
(a)

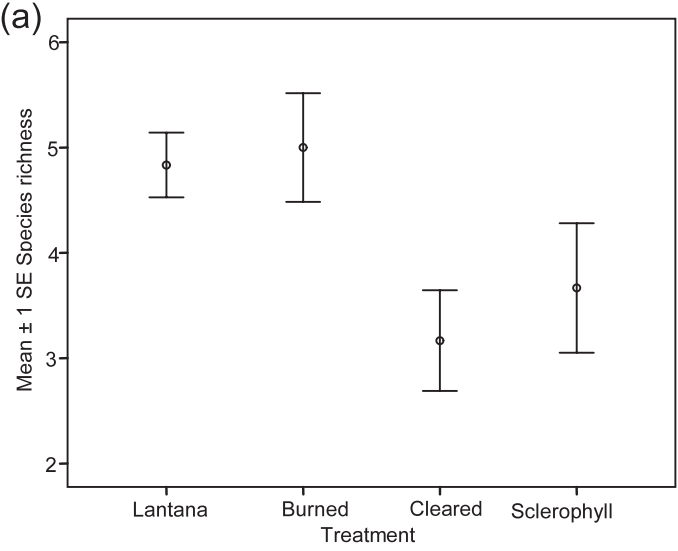

(b)

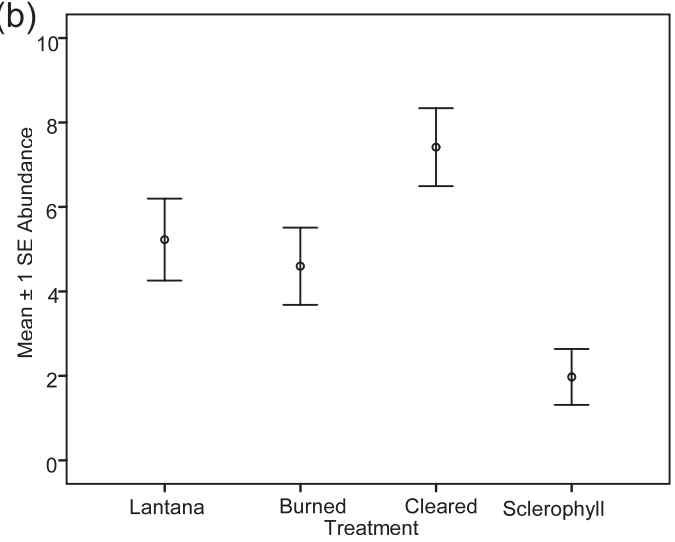

FIG. 2. Mean ( \pm SE) (a) species richness and (b) reptile abundance (captures/hour) among replicate plots within each treatment.

(Kanowski et al., 2006) and, although litter was not correlated with $S$. rosei in this study, litter cover is typically dense within lantana patches (Stock, 2005) (Table 2); this may lead to S. rosei favoring lantana.

Management Implications.-This study shows that the composition of reptile communities is significantly different in lantana and lantana-managed sites. While our study was confined to a small experimental analysis, these data provide some preliminary insight into the potential value of lantana, specifically for reptile communities. As such, the study provides the basis to test these responses in order to assess their general applicability.

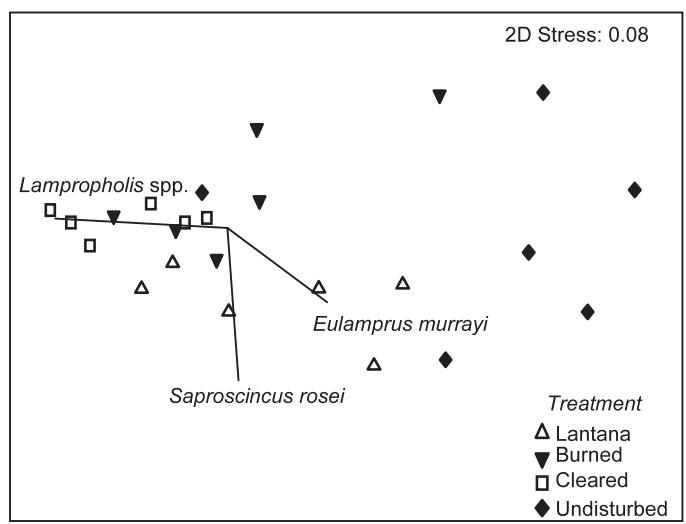

FIG. 3. Two-dimensional MDS of reptile composition of all species observed (captures/hour) among treatments with highly correlated $(r>$ $0.5)$ reptile species. Each point represents a replicate plot.

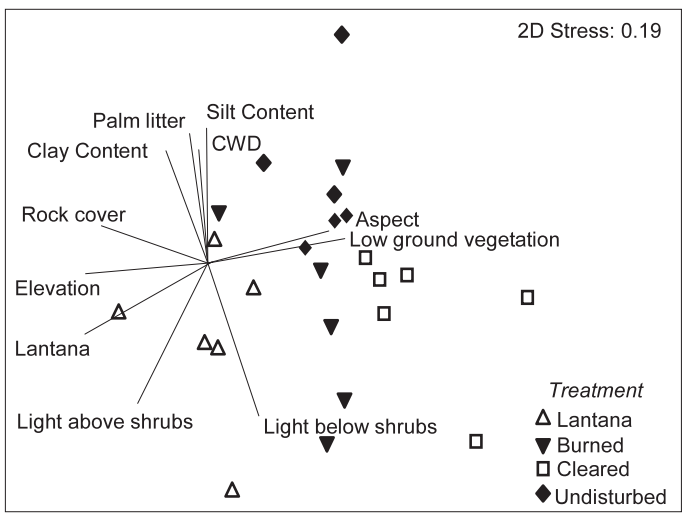

FIG. 4. Two-dimensional MDS of habitat attributes among treatments with highly correlated $(r>0.5)$ habitat attributes. Each point represents a replicate plot.

As our study demonstrates, long-established lantana habitats are not devoid of reptile species, and land managers will need to consider the implications of control or eradication programs prior to deciding on appropriate interventions. Importantly, in these wet sclerophyll forests, lantana supported relatively high numbers of rare species, particularly $S$. rosei, emphasizing the need to consider the conservation requirements for such species. Despite the presence of a variety of species within lantana habitats, there were no species restricted to these areas, and management interventions that stagger control operations may allow more species to colonize adjacent suitable habitats. The effects caused by the treatment strategy, particularly on habitat structure, and the use of lantana patches as habitat by particular reptile species suggests the importance of adopting a mosaic strategy to lantana management. However, little research has been done on the recovery or resilience of reptile species in wet sclerophyll landscapes following weed management. Reptiles are not as mobile as other vertebrates, e.g., birds, and are therefore not believed to recover as readily, which poses conservation concerns (Mac Nally and Brown, 2001; Johnson et al., 2007).

Our study reveals that the combination of herbicide and burning controlled lantana encouraged the recovery of natural vegetation at this site and maintained diverse reptile communities. This diversity of reptiles may have resulted from the initial regrowth of vegetation in the burned sites, paired with the high percentage cover of CWD and litter, thus increasing structural diversity and heterogeneity. Heterogeneous environments commonly support a greater variety of reptile species (Brown, 2001; Fischer et al., 2005), and this has significant management and conservation implications, as prescribed burning is an integral part of the management of forest reserves in Australia (Whelan, 1995; Clarke, 2008; Valentine and Schwarzkopf, 2009).

The results from our study are not consistent with the negative fire responses of reptiles reported in the past (McLeod and Gates, 1998; Singh et al., 2002; Andersen et al., 2005) and may be due to the fact that AWC used a smaller-scale, lowerintensity burn while allowing more than 6 months recovery before our initial surveys. The use of lower intensity or patchy mosaic fires seems to allow reptiles to move into nearby unburned habitat and, consequently, this technique is therefore advocated to limit negative effects caused by the fires (Valentine and Schwarzkopf, 2009). In comparison to other treatment types, burning may enhance reptile diversity because it removes 
TABLE 2. One-way ANOVA F-values for habitat attributes and treatment means.

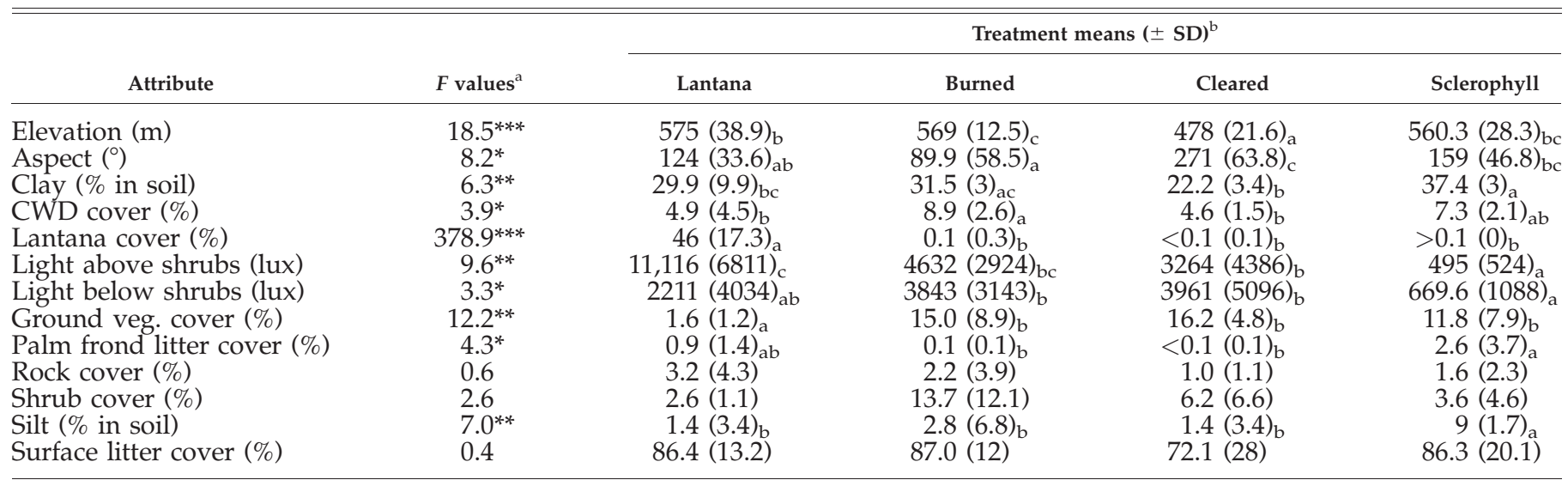

a Significant values and values approaching significance: ${ }^{*} P<0.05 ;{ }^{* *} P<0.01 ;{ }^{* * *} P<0.001$.

${ }^{\mathrm{b}}$ If subscripted, lower-case letters next to values differ, means are significantly different according to LSD post hoc tests $(P<0.05)$.

non-preferred, weedy, non-native litter (Valentine et al., 2007; Mott et al., 2010).

Our study delivers two key messages. First, lantana can support diverse reptile communities and, second, herbicide application followed by low-intensity burns provides an effective mechanism to control lantana but still maintain diverse reptile communities. These observations provide the basis for further testing at a landscape scale. We also acknowledge that lantana management in Australia is complicated by potentially conflicting objectives in the conservation management of wet sclerophyll forests (Unwin, 1989; Williams, 2000). There is ongoing debate over the 'natural' state of these forests, which range from grassy to a rainforest understory (Williams, 2000), and over the role of fire in maintaining the fluid ecotone between wet sclerophyll and rainforest ecosystems (Bowman, 2000; Bradstock et al., 2005). However, consideration of faunal communities in land management is increasingly important, and this study demonstrates the need to monitor the outcomes of weed management.

Future control measures aimed at reducing the extent of lantana while restoring native vegetation communities must consider the potential implications for faunal communities. Because lantana is widespread across the globe, our study has implications in many countries. This is particularly imperative in the context of reptile conservation, as reptiles can have small home ranges and often exhibit an inability to move on to more suitable habitat after large-scale vegetation clearing has taken place (Johnson et al. 2007).

Acknowledgments.-This study was supported by the Australian Government's Defeating the Weeds Menace Initiative through the National Lantana Management Group and the Plan to Protect Environmental Assets from Lantana Project; the Environmental Futures Centre at Griffith University; and the Peter Rankin Trust fund for Herpetology at the Australian Museum. Access to the study site was provided by the Australian Wildlife Conservancy. We thank K. Runde, L. Capill, J. Ledbetter, M. Virkki, R. Pearson, and numerous students for field assistance and M. Arthur, P. Turner, K. Dawkins, and C. Simpkins for comments and statistical advice on the manuscript. The Animal Ethics Committee of Griffith University permitted the study under the permit ENV/09/08. The manuscript has benefited from the comments of three anonymous reviewers.

\section{Literature Cited}

Andersen, A. N., G. D. Cook, L. K. Corbett, M. M. Douglas, R. W. Eager, J. Russell-Smith, S. A. Setterfield, R. J. Williams, and J. C. Z. WOINARSKI. 2005. Fire frequency and biodiversity conservation in Australian tropical savannas: implications from the Kapalga fire experiment. Australian Journal of Ecology 30:155-167.

Bowman, D. M. J. S. 2000. Australian Rainforests: Islands of Green in a Land of Fire. Centre for Indigenous Natural and Cultural Resource Management and the School of Biological and Environmental Sciences, Northern Territory University, Darwin, Australia.

Bradstock, R. A., J. E. Williams, and A. M. Gill. 2005. Flammable Australia: The Fire Regimes and Biodiversity of a Continent. Cambridge University Press, Cambridge, UK.

BRown, G. W. 2001. The influence of habitat disturbance on reptiles in a box-ironbark eucalypt forest of south-eastern Australia. Biodiversity and Conservation 10:161-176.

CHAH. Australia's Virtual Herbarium [Internet]. Council of Heads of Australasian Herbaria Inc., Canberra; 2010 [cited 2011 Sep 4]. Available from: http://www.chah.gov.au.

Clarke, K. R., AND M. Ainsworth. 1993. A method of linking multivariate community structure to environmental variables. Marine Ecology Progress Series 92:205-219.

Clarke, K. R., and R. N. Gorley. 2006. PRIMER v6: user manual / tutorial. PRIMER-E, Plymouth, UK.

Clarke, K. R., and R. M. Warwick. 1994. Change in Marine Communities: An Approach to Statistical Analysis and Interpretation. Natural Environment Research Council, Swindon, UK.

Clarke, M. F. 2008. Catering for the needs of fauna in fire management: science or just wishful thinking? Wildlife Research 35:385-394.

Croft, P., N. Reid, AND J. T. Hunter. 2010. Experimental burning changes the quality of fallen timber as habitat for vertebrate and invertebrate fauna: implications for fire management. Wildlife Research 37:574581.

Day, M. D., C. J. Wiley, J. Playford, and M. P. Zalucki. 2003. Lantana: Current Management Status and Future Prospects. Australian Centre for International Agricultural Research Monograph, Canberra, Australia.

DECC. Managing the impact of lantana on biodiversity: a national challenge [Internet]. New South Wales; 2008 [cited 2008 Jul 12]. Available from: http://www.environment.nsw.gov.au/pestsweeds/ Lantana.htm.

Downes, S., AND A. M. Hoefer. 2007. An experimental study of the effects of weed invasion on lizard phenotypes. Oecologia 153:775-785.

EPA. Regional ecosystems [Internet]. Environmental Protection Agency, Queensland; 2008 [cited 2008 Sep 3]. Available from: http:// 
www.epa.qld.gov.au/nature_conservation/biodiversity/regional_ ecosystems/.

Fensham, R. J., R. J. Fairfax, and R. J. Cannell. 1994. The invasion of Lantana camara L. in Forty Mile Scrub National Park, north Queensland. Australian Journal of Ecology 19:297-305.

Fischer, J., D. B. LindenMaYer, AND A. CowLing. 2004. The challenge of managing multiple species at multiple scales: reptiles in an Australian grazing landscape. Journal of Applied Ecology 41:32-44.

Fischer, J., D. B. LindenMayer, S. Barry, and E. Flowers. 2005. Lizard distribution patterns in the Tumut fragmentation "natural experiment" in south-eastern Australia. Biological Conservation 123:301315.

Garden, J. G., C. A. McAlpine, H. P. Possingham, and D. N. Jones. 2007. Habitat structure is more important than vegetation composition for local-level management of native terrestrial reptile and small mammal species living in urban remnants: a case study from Brisbane, Australia. Austral Ecology 32:669-685.

Gentle, C. B., AND J. A. Duggin. 1997. Allelopathy as a competitive strategy in persistent thickets of Lantana camara L. in three Australian forest communities. Plant Ecology 132:85-95.

Gentle, C. B., AND J. A. Duggin. 1998. Interference of Choricarpia leptopetala by Lantana camara with nutrient enrichment in mesic forests on the central coast of NSW. Plant Ecology 136:205-211.

Gooden, B., K. French, and P. J. Turner. 2009a. Invasion and management of a woody plant, Lantana camara L., alters vegetation diversity within wet sclerophyll forest in southeastern Australia. Forest Ecology and Management 257:960-967.

Gooden, B., K. French, P. J. Turner, and P. O. Downey. 2009b. Impact threshold for an alien plant invader, Lantana camara L., on native plant communities. Biological Conservation 142:2631-2641.

Goosem, M., Y. IzUmi, AND S. TURTON. 2001. Efforts to restore habitat connectivity for an upland tropical rainforest fauna: a trial of underpasses below roads. Ecological Management and Restoration 2:196-202.

Goosem, M., N. Weston, And S. Bushnell. 2006. Effectiveness of rope bridge arboreal overpasses and faunal underpasses in providing connectivity for rainforest fauna. In C. L. Irwin, P. Garrett, and K. P. McDermott (eds.), The 2005 International Conference on Ecology and Transportation, pp. 304-316. Center for Transportation and the Environment, North Carolina State University, North Carolina.

Goth, A., AND U. Vogel. 2002. Chick survival in the megapode Alectura lathami (Australian Brush-turkey). Wildlife Research 29:503-511.

Groves, R. H., J. R. Hosking, G. N. Batianoff, D. A. Cooke, I. D. Cowie, R. W. Johnson, G. J. Keighery, B. J. Lepschi, A. A. Mitchell, M. Moerkerk, ET AL. 2003. Weed Categories for Natural and Agricultural Ecosystem Management. Bureau of Rural Sciences, Canberra, Australia.

Hadden, S. A., AND M. E. WestbRoOKE. 1996. Habitat relationships of the herpetofauna of remnant buloke woodlands of the Wimmera Plains, Victoria. Wildlife Research 23:363-372.

Hiremath, A. J., AND B. Sundaram. 2005. The fire-lantana cycle hypothesis in Indian forests. Conservation and Society 3:26-42.

HobBS, R. J., AND S. E. HumpHRIES. 1995. An integrated approach to the ecology and management of plant invasions. Conservation Biology 9:761-770

Irschick, D. J., E. Carlisle, J. Elstrott, M. Ramos, C. Buckley, B. VanhooydoncK, J. Meyers, and A. Herrel. 2005. A comparison of habitat use, morphology, clinging performance and escape behaviour among two divergent Green Anole Lizard (Anolis carolinensis) populations. Biological Journal of the Linnean Society 85:223-234.

IsLAM, K. R., AND R. R. WeIL. 2000. Land use effects on soil quality in a tropical forest ecosystem of Bangladesh. Agriculture, Ecosystems and Environment 79:9-16.

Johnson, C., H. Cogger, C. Dickman, And H. Ford. 2007. Impacts of Landclearing; The Impacts of Approved Clearing of Native Vegetation on Australian Wildlife in New South Wales. WWFAustralia Report. WWF-Australia, Sydney.

Kanowski, J. J., T. M. Reis, C. P. Catterall, and S. D. Piper. 2006. Factors affecting the use of reforested sites by reptiles in cleared rainforest landscapes in tropical and subtropical Australia. Restoration Ecology 14:67-76.

KReBS, C. J. 2003. Two complementary paradigms for analysing population dynamics. In R. M. Sibly, J. Hone, and T. H. CluttonBrock (eds.), Wildlife population growth rates. Cambridge University Press, Cambridge, UK.

Letnic, M., C. R. Dickman, M. K. Tischler, B. Tamayo, and C. L. Beh. 2004. The responses of small mammals and lizards to post-fire succession and rainfall in arid Australia. Journal of Arid Environments 59:85114.

LiDDY, J. 1985. A note on the associations of birds and lantana near Beerburrum, south-eastern Queensland. Corella 9:125-126.

Lindenmayer, D., C. MacGregor, J. Wood, R. Cunningham, M. Crane, D. Michael, R. Montague-Drake, D. Brown, M. Fortescue, N. Dexter, et AL. 2009. What factors influence rapid post-fire site re-occupancy? A case study of the endangered Eastern Bristlebird in eastern Australia. International Journal of Wildland Fire 18:84-95.

Mac Nally, R., and G. W. Brown. 2001. Reptiles and habitat fragmentation in the box-ironbark forests of central Victoria, Australia: predictions, compositional change and faunal nestedness. Oecologia 128:116-125.

Magnusson, W. E., A. P. Lima, R. Luizão, F. R. C. Costa, C. V. de Castilho, AND V. F. KINUPP. 2005. RAPELD: a modification of the Gentry method for biodiversity surveys in long-term ecological research sites. Biota Neotropica 5:1-6.

McDonald, R. C., R. F. Isbell, J. G. Speight, J. Walker, and M. S. Hopkins. 1998. Australian Land and Soil Survey. CSIRO Australia, Canberra, Australia.

McLeOd, R. F., AND J. E. Gates. 1998. Response of herpetofaunal communities to forest cutting and burning at Chesapeake Farms, Maryland. American Midland Naturalist 139:164-177.

Mott, T., R. A. Alford, and L. SchwarzKopf. 2010. Tropical reptiles in pine forests: responses to plantations and plantation management by burning. Forest Ecology and Management 259:916-925.

NHT. 2003. Weed management guide-lantana [Internet]. National Heritage Trust, Australian Government, Australia [cited 2008 Mar 20]. Available from: www.weeds.gov.au/publications/guidelines/ wons/pubs/l-camara.pdf.

NORKKO, J., E. BONSDORFF, AND A. NORKKO. 2000. Drifting algal mats as an alternative habitat for benthic invertebrates: species-specific responses to a transient resource. Journal of Experimental Marine Biology and Ecology 248:79-104.

PickEtT, S. T. A. 1991. Space-for-time substitution as an alternative to long-term studies. In G. E. Likens (ed.), Long-term Studies in Ecology: Approaches and Alternatives, pp. 110-135. Springer-Verlag, New York.

Sharma, G. P., A. S. Raghubanshi, AND J. S. Singh. 2005. Lantana invasion: an overview. Weed Biology and Management 5:157-165.

Sharma, O. P., S. Sharma, V. Pattabhi, S. B. Mahato, and P. D. Sharma. 2007. A review of the hepatotoxic plant Lantana camara. Critical Reviews in Toxicology 37:313-352.

Sinden, J. A., AND G. GRIFFITH. 2007. Combining economic and ecological arguments to value the environmental gains from control of 35 weeds in Australia. Ecological Economics 61:396-408.

Singh, S., A. K. SMYTH, AND S. P. BlomberG. 2002. Effect of a control burn on lizards and their structural environment in a eucalypt open-forest. Wildlife Research 29:447-454.

Smith, G. C., J. ARIDIS, AND N. LeEs. 1998. Radio-tracking revealed home ranges of Black-breasted Button-quail Turnix melanogaster in remnant vine scrub between hoop pine plantation and agriculture. Emu 98: 171-177.

Stock, D., K. Johnson, A. Clark, and E. van Oosterhout. 2009. Lantana Best Practice Manual and Decision Support Tool. The State of Queensland, Department of Employment, Economic Development and Innovation, Yeerongpilly, Australia.

Sтоск, D. H. 2005. The dynamics of Lantana camara (L.) invasion of subtropical rainforest in southeast Queensland, Unpubl. PhD thesis. Griffith University, Gold Coast, Australia.

Sutherland, W. J. 2006. Ecological Census Techniques. Cambridge University Press, Cambridge, UK.

Swarbrick, J. T., B. W. Willson, and M. A. Hannan-Jones. 1995. The biology of Australian weeds 25. Lantana camara L. Plant Protection Quarterly 10:82-95.

Thuiller, W., D. M. Richardson, P. Pysek, G. F. Midgley, G. O. Hughes, AND M. ROUGET. 2005. Niche-based modeling as a tool for predicting the risk of alien plant invasions at a global scale. Global Change Biology 11:2234-2250.

Totland, O., P. Nyeko, A. L. Bjerknes, S. J. Hegland, and A. Nielsen. 2005. Does forest gap size affect population size, plant size, reproductive success and pollinator visitation in Lantana camara, a tropical invasive shrub? Forest Ecology and Management 215:329338.

TuRnER, P. 2007. Wildfire Chronosequence Establishment Report. Report No. B.07.01. Bushfire CRC, Tasmania, Australia. 
Turner, P. J., AND P. O. Downey. 2008. The role of native birds in weed invasion, species decline, revegetation and reinvasion: consequences for lantana management. In R. D. van Klinken, V. A. Osten, F. D. Panetta, and J. C. Scanlan (eds.), The 16th Australian Weeds Conference, pp. 30-32. Queensland Weeds Society, Brisbane, Australia.

Turner, P. J., AND P. O. Downey. 2010. Ensuring invasive alien plant management delivers biodiversity conservation: insights from an assessment of Lantana camara in Australia. Plant Protection Quarterly 25:102-110.

Tyre, A. J., B. Tenhumberg, M. S. McCarthy, and H. P. Possingham. 2000. Swapping space for time and unfair tests of ecological models. Austral Ecology 25:327-331.

UnwIN, G. L. 1989. Structure and composition of the abrupt rainforest boundary in the Herberton Highland, north Queensland. Australian Journal of Botany 37:413-428.

Urbina-Cardona, J. N., M. Olivares-Pérez, and V. H. Reynoso. 2006. Herpetofauna diversity and microenvironment correlates across a pasture-edge-interior ecotone in tropical rainforest fragments in the Los Tuxtlas Biosphere Reserve of Veracruz, Mexico. Biological Conservation 132:61-75.
VALENTine, L. E., AND L. SchwARZKopf. 2009. Effects of weed-management burning on reptile assemblages in Australian tropical savannas. Conservation Biology 2:1-11.

Valentine, L. E., B. Roberts, and L. SchwarzKopf. 2007. Mechanisms driving avoidance of non-native plants by lizards. Journal of Applied Ecology 44:228-237.

Whelan, R. J. 1995. The Ecology of Fire. Cambridge University Press, Cambridge, UK.

WiLliams, P. R. 2000. Fire-stimulated rainforest seedling recruitment and vegetative regeneration in a densely grassed wet sclerophyll forest of north-eastern Australia. Australian Journal of Botany 48:651-658.

WILSON, S. 2005. A Field Guide to Reptiles of Queensland. New Holland Publishers, Sydney, Australia.

ZAR, J. H. 2007. Biostatistical Analysis, 5th ed. Prentice-Hall, Upper Saddle River, New Jersey.

Zavaleta, E. S., R. J. Hobbs, and H. A. Mooney. 2001. Viewing invasive species removal in a whole-ecosystem context. Trends in Ecology and Evolution 16:454-459.

Accepted: 16 January 2012. 